УДК 657.62

Іонін Є.Є., д.е.н., професор, завідувач кафедри обліку, аналізу і аудиту Донецького національного університету ім. Василя Стуса

Єгорова А.О., магістрант Донецького національного університету ім. Василя Стуса

\title{
ОБЛІКОВО-АНАЛІТИЧНЕ ЗАБЕЗПЕЧЕННЯ ФІНАНСОВИХ ІНВЕСТИЦІЙ ГІРНИЧО-ЗБАГАЧУВАЛЬНИХ КОМБІНАТІВ
}

У статті розкрито методику аналізу інвестиційної привабливості фінансових інвестицій гірничо-збагачувальних комбінатів, що може бути застосована як внутрішніми, так і зовнішніми користувачами. Аналіз інвестиційної привабливості передбачає використання системи індикаторів платоспроможності, фінансової стійкості, рентабельності, ділової активності. Обов'язковою вимогою є проведення наступних аналітичних процедур: горизонтальний аналіз показників фінансової звітності за рік, оцінка загального фінансового стану на основі даних фінансової звітності, визначення типів фінансової стійкості та прогнозування вартості фінансових інвестицій.

Методику застосовано на прикладі показників консолідованої фінансової звітності гірничо-збагачувальних комбінатів Групи за 2016 - 2017 рр.

Ключові слова: фінансові інвестиції, інвестиційна привабливість, фінансова звітність, аналіз, фінансова незалежність, оцінка, капітал.

Табл. 4, Рис. 2, Літ. 7

Ионин Е.Е., Егорова А.А.

УЧЕТНО-АНАЛИТИЧЕСКОЕ ОБЕСПЕЧЕНИЕ ФИНАНСОВЫХ ИНВЕСТИЦИЙ ГОРНО-ОБОГАТИТЕЛЬНЫХ КОМБИНАТОВ

В статье раскрыта методика анализа инвестиционной привлекательности финансовых инвестиций горно-обогатительных комбинатов, может быть применена как внутренними, так и внешними пользователями. Анализ инвестиционной привлекательности предусматривает использование системы индикаторов платежеспособности, финансовой устойчивости, рентабельности, деловой активности. Обязательным требованием является проведение следующих аналитических процедур: горизонтальный анализ показателей финансовой отчетности за год, оценка общего финансового состояния на основе данных финансовой отчетности, определение типов финансовой устойчивости и прогнозирования стоимости финансовых инвестиций.

Методика применена на примере показателей консолидированной финансовой отчетности горно-обогатительных комбинатов Группы по 2016 - 2017 гг.

Ключевые слова: финансовые инвестиции, инвестиционная привлекательность, финансовая отчетность, анализ, финансовая независимость, оценка, капитал.

Ionin E., Yehorova A.

\section{ACCOUNTING AND ANALYTICAL SUPPORT OF FINANCIAL INVESTMENTS OF MINING AND PROCESSING COMBINATES}

In the article the method of analysis of investment attractiveness of financial investments of mining and concentrating mills is opened, which can be applied both by 
internal and external users. Analysis of investment attractiveness involves the use of a system of indicators of solvency, financial stability, profitability, business activity. A mandatory requirement is to conduct the following analytical procedures: horizontal analysis of the financial statements for the year, assessing the overall financial condition based on financial statements, determining the types of financial stability and forecasting the value of financial investments.

The method is applied on the example of the indicators of the consolidated financial statements of the Group's ore mining and processing enterprises for 2016-2017.

Key words: financial investments, investment attractiveness, financial reporting, analysis, financial independence, estimation, capital.

Постановка проблеми. В умовах низького рівня державної підтримки бізнесу, дестабілізації національного банківського сектора та зниження ефективності діяльності вітчизняних підприємств істотно зростає потреба у додатковому капіталі, найбільш оптимальним 3 позиції термінів залучення та вартості якого є використання інструментів фінансових інвестицій, тобто залучення/розміщення інвестицій у цінні папери шляхом їх придбання в процесі емісії чи обігу. Динаміка зміни валового внутрішнього продукту (ВВП) України та обсягів прямих інвестиційних вкладень показує про певний дисбаланс. Якщо ВВП за 2010-2017 рр. збільшився у 2,76 рази (2010 р. 1079,3 млрд. грн., 2017 р. 2982,9 млрд. грн.), то прямі інвестиційні вкладення у капітал суб'єктів господарювання тільки на 0,4\% (2010 р. 38993 млн. грн., 2017 р. 39144 млн. грн.) [1].

Спостережувана тенденція говорить про низьку активність інвестиційної діяльності в країні та низьку зацікавленість інвесторів до інвестиційних вкладень. Однією з причин виникнення такого явища $є$ приділення недостатньої уваги формуванню інвестиційного іміджу суб'єкта господарювання як зі сторони державних органів, так і зі сторони управлінського персоналу підприємств. Вихідне явище такого характеру є наслідком пізнього та повільного впровадження ринкових відносин в економічне середовище незалежної України.

У сучасних умовах господарювання аналіз інвестиційної привабливості та інвестиційної діяльності підприємства повинен грати ключову роль у процесі прийняття управлінських рішень. Особливе значення це має для гірничо-металургійного комплексу (ГМК) України, який забезпечує до $35 \%$ валютних надходжень та займає до $40 \%$ національного експорту. Фундаментальною основою ГМК України $є$ гірничо збагачувальні комбінати (ГЗК). Економічна криза призвела до скорочення попиту на металургійну продукцію, стала причиною нездатності підприємств металургійного комплексу повністю фінансувати власну діяльність, що викликало необхідність залучення додаткових джерел отримання коштів, зокрема отримання доходу від утримання, придбання, продажу та перепродажу фінансових інвестицій.

Аналіз останніх досліджень. Питання дослідження методики оцінки інвестиційної привабливості та інвестиційної діяльності підприємства висвітлено у роботах зарубіжних та вітчизняних науковців: І. Бланка, Л. Бернстайна, О. Гончаренка, А. Вічевича, О. Русіної, М. Зинюка, Г. Клейнер, Дж. Лінтера, А. Філіпченко тощо. Станом на сьогодні існує чисельна кількість методик оцінки інвестиційної привабливості, що використовують різні види аналізу. Багато з них є недоступними для зовнішніх користувачів через обмеження в інформаційних ресурсах, потреби в залученні додаткових експертів через існування низки розрахункових показників чим обумовлена актуальність дослідження.

Метою наукової статті $\epsilon$ дослідження оптимізації методики аналізу інвестиційної привабливості та інвестиційної діяльності підприємства на основі 
показників консолідованої фінансової звітності, яка відповідатиме потребам зовнішніх користувачів, шляхом компонування окремих методів аналізу.

Викладення основного матеріалу. Компаративний аналіз точок зору науковців до визначення сутності «фінансові інвестиції», їх нормативне забезпечення дає можливість зробити висновок про наявність достатньої розбіжності, відсутності єдиного підходу. У вітчизняних літературних джерелах фінансові інвестиції розглянуто 3 позиції інвесторів, в якості матеріальних вкладень у фінансові інструменти: Бланк I.О., Бутинець, Головко В.І., Пономаренко Є.Б.

Зарубіжними джерелами даний об'єкт обліку розглядається на макрорівні, як збільшення пропозиції виробничих ресурсів, на мікрорівні, як фактор, що сприяє розширенню бізнесу: Е. Дж. Долан, Д. Ліней, Л. Гітман, Ж. Перар, Ю. Блех.

Критичний аналіз нормативно-правового забезпечення фінансових інвестицій в Україні (Господарський кодекс, Податковий кодекс, Закони України «Про бухгалтерський облік та фінансову звітність в Україні», «Про інвестиційну діяльність», «Про цінні папери та фондовий ринок»; П(С)БО 12 «Фінансові інвестиції», П(С)БО 13 «Фінансові інструменти») свідчить про низку невирішених питань, що впливають на якість відображення операцій з фінансовими інвестиціями в обліку і звітності, а саме:

1) використання різних підходів до визначення сутності фінансових інвестицій у нормативних документах впливає на викривлене розуміння сутності такого об'єкту суб'єктами господарювання;

2) відсутність опису класифікаційних ознак видів фінансових інвестицій у П(С)БО є потенційною причиною некоректного віднесення фінансових інвестицій до класифікаційних груп на підприємствах та викривлення інформації у звітності;

3) виявлені проблеми та протиріччя нормативної бази обліку фінансових інвестицій потребують деякі напрями вдосконалення змісту П(С)БО 12 та Інструкції про застосування Плану рахунків бухгалтерського обліку активів, капіталу, зобов'язань і господарських операцій підприємств і організацій в частини розширення сфери дії П(С)БО 12 , доповнення Інструкції про застосування Плану рахунків бухгалтерського обліку.

У рамках дослідження інвестиційної привабливості підприємства користувачами на першому етапі доречним $\epsilon$ застосування горизонтального аналізу динаміки показників фінансової звітності, що стосуються інвестиційної діяльності, для одержання загального уявлення про якісні зміни, які відбувались у структурі, а також динаміку цих змін з метою отримання достовірної інформації про фінансовий стан, платоспроможність підприємства (табл.1) [2, 3].

Проведений горизонтальний аналіз окремих показників фінансової звітності гірничо - збагачувальних комбінатів Групи «Метінвест» характеризує високу інвестиційну привабливість підприємств та активізацію його інвестиційної діяльності у порівнянні з 2016p.

Найвищий рівень інвестиційної привабливості за первинним горизонтальним аналізом має ПрАТ «Центральний гірничо - збагачувальний комбінат», адже за результатами діяльності чисті активи збільшились на 18,6\% за рахунок збільшення чистого прибутку на 47 \% і відповідно - нерозподіленого прибутку, нарощування оборотних активів у частині грошових коштів та еквівалентів та незначного зростання поточних та довгострокових зобов'язань. Значний вплив на високий рівень інвестиційної привабливості має збільшення грошових коштів та їх еквівалентів, адже від цього показника залежить потенційна платоспроможність підприємства. 
Таблиця 1 - Динаміка основних показників фінансової звітності гірничо-збагачувальних комбінатів Групи «Метінвест» за період 1.01.2016 по 1.01.2018 р., (\%)

\begin{tabular}{|l|c|c|c|}
\hline \multicolumn{1}{|l|}{ Показники статей звітності } & ПрАТ «ПівнГЗК» & ПрАТ «ЦГЗК» & ПрАТ «ІНГЗК» \\
\hline Валюта балансу & $+24,4$ & $+12,7$ & $+20,7$ \\
\hline Річний чистий прибуток & $-20,7$ & $+47,0$ & +535 \\
\hline Оборотні активи & $+59,4$ & $+20,4$ & $+48,8$ \\
\hline Необоротні активи & $-7,6$ & $+4,5$ & $-18,0$ \\
\hline $\begin{array}{l}\text { Гроші та грошові } \\
\text { еквіваленти }\end{array}$ & $+26,3$ & $+97,4$ & $+803,1$ \\
\hline $\begin{array}{l}\text { Довгострокові фінансові } \\
\text { інвестиції }\end{array}$ & $-33,3$ & - & $-100,0$ \\
\hline $\begin{array}{l}\text { Короткострокові фінансові } \\
\text { інвестиції }\end{array}$ & - & - & - \\
\hline $\begin{array}{l}\text { Чисті активи } \\
\text { (Власний капітал) }\end{array}$ & $-20,5$ & $+18,6$ & $+52,1$ \\
\hline Поточні зобов'язання & +263 & $+6,7$ & $+7,7$ \\
\hline Довгострокові зобов’язання & $-2,0$ & $+12,4$ & $+103,9$ \\
\hline
\end{tabular}

Збільшення цього показника свідчить про позитивне значення чистого грошового потоку за рік, що цілком відповідає вимогам забезпечення безперервної діяльності, а збільшення чистих активів при прибутковості діяльності, концепції збереження фінансового капіталу.

Середній рівень інвестиційної привабливості має ПрАТ «Інгулецький гірничо збагачувальний комбінат», вартість чистих активів якого зросла на 52,1\% за рахунок збільшення нерозподіленого прибутку з 3,1 млрд. грн. до 7,8 млрд. грн., збільшення величини грошових активів та зростання рівня довгострокових зобов'язань. Зростання залежності від довгострокових позик двобічно впливає на інвестиційну привабливість 3 одного боку, це свідчить про нарощування активів та основних виробничих фондів, 3 іншого - зумовлює виникнення потенційних ризиків зростання залежності підприємства від позикових коштів та низького рівня ліквідності активів.

Низький рівень інвестиційної привабливості у ПрАТ «ПівнГЗК» обумовлено скороченням вартості чистих активів на 20,5 \%, стрімким зростанням величини поточних зобов'язань на 263 \% та зниженням чистого прибутку на 20,9 \%, а отже, підприємство є потенційно неплатоспроможним, рівень довіри інвесторів знижується.

На другому етапі після аналізу динаміки показників фінансової звітності суб'єктів господарювання виникає потреба в дослідженні змін відносних показників, розрахованих 3 метою визначення платоспроможності та фінансової стійкості підприємств.

На даний момент широкого використання набули дві методики оцінки інвестиційної діяльності та інвестиційної привабливості суб'єктів господарювання 3 використанням розрахункових показників:

1. Метод рейтингової оцінки підприємства на основі даних фінансової звітності;

2. Інтегральна оцінка інвестиційної привабливості [4, с. 14].

В умовах обмеження інформаційних ресурсів та неможливості залучення експертів до здійснення оцінки інвестиційної привабливості та інвестиційної діяльності доцільним $є$ застосування методу оцінки загального фінансового стану на основі даних фінансової звітності ГЗК Групи «Метінвест». 
3 цієї мети було використано 13 аналітичних показників (коефіцієнтів), які можна розділити на 4 основні групи:

- 4 показника ліквідності та платоспроможності: робочий капітал, коефіцієнти абсолютної ліквідності, проміжного покриття, загального покриття;

- 5 коефіцієнтів фінансової стійкості: залежності від довгострокових зобов'язань, фінансової незалежності, фінансової залежності, фінансової стабільності, боргу;

- 3 показника рентабельності: рентабельність продажу, капіталу, чистий прибуток на 1 просту акцію;

- 1 показник ділової активності: коефіцієнт оборотності активів, або активовіддача.

Для оцінки інвестиційної привабливості ГЗК Групи «Метінвест», виявлення резервів щодо ії підвищення, результати розрахунків пропонуємо градувати за шкалою від 0 до 2, де:

Для коефіцієнтів з установленим прийнятим значенням оцінка:

0 - показник виходить за межі допустимої норми;

1 - показник близький до межі допустимої норми;

2 - показник у межах допустимої норми.

Для показників без установленого прийнятного значення:

0 - негативна зміна показника;

1 - показник не змінився;

2 - позитивна зміна показника.

3 наведених 13 показників 8 коефіцієнтів мають рекомендоване значення, це коефіцієнти ліквідності та платоспроможності (3), фінансової стійкості (5). По іншим показникам: робочий капітал, коефіцієнт оборотності активів, рентабельність рекомендоване значення можна позначити як позитивне, збільшення (табл. 2).

Безумовно важливе місце серед представлених показників посідає робочих капітал, або чисті поточні активи, позитивне значення якого свідчить про потенційну платоспроможність на основі потенційних грошових потоків: вхідний та вихідний. Іншими словами, це потенційний чистий грошовий потік на касовій основі. Збільшення позитивної величини робочого капіталу $є$ слідством прибуткової роботи на основі методу нарахувань, та гарантом перспективної платоспроможності. Тому, в якості рекомендованого значення $€$ наявність позитивного результату та тенденція його відносного збільшення.

Критеріальна відповідність робочого капіталу є підгрунтям для відповідності коефіцієнтів загального покриття, абсолютної ліквідності та проміжного покриття. На останні два коефіцієнта впливає структура оборотних активів по групам ліквідності.

Серед показників фінансової стійкості в діючих вітчизняних методиках фінансового аналізу, затверджених органами виконавчої влади, посідає показник фінансової незалежності (автономії), який наочно підтверджує вимогу концепції збереження фінансового капіталу. Останні чотири коефіцієнта в цілому знаходяться у функціональної залежності від першого, рекомендоване значення якого вимагає, щоби мінімум 50 \% активів підприємства було профінансовано за рахунок власного капіталу, що зменшує ризик кредиторів та підвищує платоспроможність. Враховуючі цю норму, слід обов'язково пам'ятати, що реалістичність цього ствердження залежить від структури власного капіталу, а саме, від наявності та питомої ваги нерозподіленого прибутку та резервного капіталу у складі чистих активів.

Показник ділової активності та рентабельності продажу дають можливість інтегрувати в систему рекомендованих показників інвестиційної привабливості золоте 
правило бізнесу, яке грунтується на основі порівняння темпових показників: прибутку, продажу, активів.

Таблиця 2 - Рекомендоване значення показників інвестиційної привабливості

\begin{tabular}{|c|c|c|c|}
\hline $\begin{array}{l}\mathrm{N} \\
3 \Pi\end{array}$ & Назва & Формула розрахунку & Рекомендоване значення \\
\hline 1 & Робочий капітал & $\mathrm{WC}=\mathrm{CA}-\mathrm{CL}$ & позитивне, збільшення \\
\hline 2 & $\begin{array}{l}\text { Коефіцієнт залежності від } \\
\text { довгострокових зобов'язань }\end{array}$ & $\mathrm{K}=\frac{F L}{E}$ & $<1$ \\
\hline 3 & $\begin{array}{l}\text { Коефіцієнт абсолютної } \\
\text { ліквідності }\end{array}$ & $\mathrm{K}=\frac{C}{C L}$ & $0,2-0,25$ \\
\hline 4 & $\begin{array}{l}\text { Коефіцієнт фінансової } \\
\text { незалежності }\end{array}$ & $\mathrm{K}=\frac{E}{T A}$ & $\geq 0,5$ \\
\hline 5 & $\begin{array}{l}\text { Коефіцієнт фінансової } \\
\text { залежності }\end{array}$ & $\mathrm{K}=\frac{T A}{E}$ & $\leq 2$ \\
\hline 6 & $\begin{array}{l}\text { Коефіцієнт фінансової } \\
\text { стабільності }\end{array}$ & $\mathrm{K}=\frac{E}{L}$ & $>1$ \\
\hline 7 & Коефіцієнт боргу & $\mathrm{K}=\frac{L}{T A}$ & $<0,5$ \\
\hline 8 & $\begin{array}{l}\text { Коефіцієнт проміжного } \\
\text { покриття }\end{array}$ & $\mathrm{K}=\frac{C+S T F I+D}{C L}$ & $0,7-0,8$ \\
\hline 9 & Коефіцієнт загального покриття & $\mathrm{K}=\frac{C A}{C L}$ & $>1$ \\
\hline 10 & Коефіцієнт оборотності активів & $\mathrm{K}=\frac{S}{T A}$ & збільшення \\
\hline 11 & Рентабельність продажу & $\mathrm{K}=\frac{p}{s}$ & позитивне, збільшення \\
\hline 12 & Рентабельність капіталу & $\mathrm{K}=\frac{P}{E}$ & позитивне, збільшення \\
\hline 13 & $\begin{array}{l}\text { Чистий прибуток на } 1 \text { просту } \\
\text { акцію }\end{array}$ & $\mathrm{K}=\frac{N P}{N O S}$ & позитивне, збільшення \\
\hline
\end{tabular}

умовні позначення: WC - робочий капітал; CA - поточні активи; CL - поточні зобов'язання; FL - довгострокові зобов'язання; Е - власний капітал; C - грошові кошти; TA валюта балансу; L - зобов'язання (поточні + довгострокові); STFI - короткострокові фінансові інвестиції; D - дебіторська заборгованість; S - чиста виручка від реалізації; Р - прибуток; NP чистий прибуток; NOS - середньозважена кількість простих акцій.

Таким чином, максимальна кількість балів - 26. Якщо результат оцінки 0 - 7 балів - інвестиційна привабливість низька, 8 - 16 - середня, 17 - 26 - висока. Результати оцінки інвестиційної привабливості ГЗК Групи «Метінвест» наведено в таблиці 3.

За результатами поглибленого аналізу фінансової стійкості, платоспроможності гірничо - збагачувальних комбінатів та оцінки інвестиційної привабливості сформовано наступні твердження:

$\checkmark$ Уніфікована облікова політика та єдиний підхід до здійснення бухгалтерського обліку на ГЗК Групи «Метінвест» мають різний вплив на формування показників звітності таких підприємств;

$\checkmark$ Станом на сьогодні, гірничо - збагачувальні комбінати знаходяться у зоні ризику неплатоспроможності через низький рівень ліквідності;

$\checkmark$ Високу ступінь інвестиційної привабливості має ПрАТ «ПівнГЗК», ПрАТ «ЦГЗК» та ПрАТ «ІнГЗК» мають середній рівень інвестиційної привабливості. 
Таблиця 3 - Оцінка інвестиційної привабливості гірничо - збагачувальних комбінатів Групи «Метінвест за показниками звітності 2017 року

\begin{tabular}{|l|c|c|c|}
\hline \multicolumn{1}{|c|}{ Показники } & $\begin{array}{c}\text { ПрАТ } \\
\text { «ПівнГЗК» }\end{array}$ & $\begin{array}{c}\text { ПрАТ } \\
\text { «ЦГК }\end{array}$ & $\begin{array}{c}\text { ПрАТ } \\
\text { «нГЗК» }\end{array}$ \\
\hline Робочий капітал підприємства & 2 & 2 & 2 \\
\hline $\begin{array}{l}\text { Коефіцієнт залежності підприємства від } \\
\text { довгострокових зобов' язань }\end{array}$ & 2 & 2 & 2 \\
\hline Коефіцієнт абсолютної ліквідності & 0 & 0 & 0 \\
\hline Коефіцієнт фінансової незалежності & 2 & 2 & 0 \\
\hline Коефіцієнт фінансової залежності & 2 & 2 & 0 \\
\hline Коефіцієнт фінансової стабільності & 2 & 1 & 0 \\
\hline Коефіцієнт боргу & 1 & 1 & 0 \\
\hline Коефіцієнт проміжного покриття & 0 & 1 & 1 \\
\hline Коефіцієнт загального покриття & 2 & 2 & 2 \\
\hline Коефіцієнт оборотності активів & 2 & 1 & 2 \\
\hline Рентабельність продажу & 2 & 0 & 2 \\
\hline Рентабельність капіталу & 2 & 2 & 2 \\
\hline Чистий прибуток на 1 просту акцію & 2 & 2 & 11 \\
\hline Загальний бал & 17 & 14 & \\
\hline
\end{tabular}

Значний вплив на прийняття рішень щодо ефективного використання фінансових інвестицій на підприємствах має визначення типу фінансової стійкості.

За О.Ю Русіною, фінансово стійким є підприємство, яке характеризується такими ознаками: високою платоспроможністю (здатністю відповідати за своїми зобов'язаннями); високою кредитоспроможністю (здатністю платити за кредитами, виплачувати відсотки по них і погашати їх точно в строк); високою рентабельністю (прибутковістю, що дозволяє нормально і стійко розвиватися, вирішуючи при цьому проблему взаємини акціонерів і менеджерів за рахунок підтримки на достатньому рівні дивідендів і курсу акцій підприємства); високою ліквідністю балансу (здатністю покривати свої пасиви активами відповідної і перевищує терміновості перетворення їх на гроші) [5, с. 92].

На нашу думку цей перелік рис фінансової стійкості можна скоротити і на перше місце поставити незалежність від зовнішніх джерел, тобто спроможність у більшому ступеню фінансувати свою діяльність за рахунок власного капіталу, що відповідає базової концепції бухгалтерського обліку - концепції збереження фінансового капіталу. 3 іншого боку слід пам'ятати, що збільшення чистих активів $є$ підставою визнання отримання прибутку [6, с.171-176].

Систему показників інвестиційної привабливості необхідно доповнити розрахунком визначення типу фінансової стійкості (від абсолютної до критичного фінансового стану), яка має достатньо тривалий час їі використання, орієнтована на виробничі підприємства, та знайшла відображення у роботах Ковальова В.В., Мниха Є.В., Шеремета А.Д., та інших авторів. Ідея цієї методики полягає у порівнянні двох важливіших показників: наявності власних оборотних коштів (3 урахуванням довгострокових зобов'язань) і запасів та витрат.

Нормою бізнесу є фінансування мінімум $10 \%$ оборотних активів за рахунок власного капіталу. 3 іншого боку, запаси, як складова частина оборотних активів, повинні бути покрити за рахунок власних джерел, що відповідає першому (без 
врахування довгострокових зобов'язань), та другому типу фінансової стійкості (з рахуванням довгострокових зобов'язань). Ця ситуація є індикатором у фінансовому аналізі, відповідно: абсолютної фінансової стійкості (I тип) і нормальної фінансової стійкості (II тип), у фінансовому менеджменті - агресивної та компромісної моделі фінансування оборотних активів [7, с.27].

Розрахунок показників для визначення типу фінансової стійкості гірничо збагачувальних комбінатів Групи «Метінвест» на 31.12.2017 наведено в таблиці 4.

Таблиця 4 - Визначення типу фінансової стійкості ГЗК Групи «Метінвест», на кінець року

\begin{tabular}{|l|l|l|c|}
\hline \multicolumn{1}{|l|}{ ГЗК Рік } & \multicolumn{1}{|l|}{ ПрАТ «ПівнГЗК» } & ПрАТ «ЦГЗК» & ПрАТ «ІнГЗК» \\
\hline $\begin{array}{l}2016 \text { р., тис. } \\
\text { грн }\end{array}$ & $\begin{array}{l}30101742- \\
19293401>809690\end{array}$ & $\begin{array}{l}6097569+757079- \\
\text { І тип }\end{array}$ & $\begin{array}{c}8943169+1375904- \\
16984122<878090 \\
\text { IV тиII }\end{array}$ \\
\hline $\begin{array}{l}2017 \text { p., тис. } \\
\text { грн }\end{array}$ & $\begin{array}{l}23928348+2119909- \\
18407722<1028548\end{array}$ & $\begin{array}{l}7121893-6406783> \\
\text { IV тиI }\end{array}$ & $\begin{array}{l}14308489-13909979> \\
738383\end{array}$ \\
\hline
\end{tabular}

За результатами розрахунків видно, що в динаміці гірничо - збагачувальні комбінати Групи «Метінвест» мають нестабільне фінансове становище, що пояснюється різкою зміною типів фінансової стійкості. Значні коливання розміру власного капіталу та зростання залежності від позикового капіталу обумовлюють зниження зацікавленості інвесторів у вкладанні власних ресурсів у розвиток таких суб'єктів господарювання через наявність ризикових факторів. Кризовий тип фінансової стійкості станом на 31 грудня має ПрАТ «ПівнГЗК», що підтверджується зниженням чистого прибутку на 20,7\%, збільшенням величини поточних зобов'язань на $263 \%$, а отже ризик неплатоспроможності є високим.

ПрАТ «ІнГЗК» має абсолютну фінансову стійкість, що у порівнянні з показником минулого року є позитивним для підприємства, але зовнішнім користувачам необхідно звернути увагу на розбіжність темпових показників: чистого прибутку, грошових коштів і чистих активів, адже величина чистого річного прибутку зросла на $535 \%$, грошових коштів - на 803,1\% на фоні збільшення чистих активів тільки на 52,1\%. Безумовно на це вплинуло: отримання прибутку у 2017 р., при наявності збитків у 2016 p., зменшення балансової статті капітал у дооцінках у 2017 р. на 17\%.

Стабільність розвитку спостерігається у ПрАТ «ЦГЗК», що має абсолютну фінансову стійкість, різких коливань фінансових показників не виявлено, спостерігається помірне нарощення чистого прибутку, власного капіталу, зростання величини оборотних активів та незначне збільшення величини поточних та довгострокових зобов'язань.

Ефективність використання фінансових інвестицій на підприємствах характеризує такий показник діяльності, як вартість довгострокових фінансових інвестицій Групи «Метінвест» на дату подання фінансової звітності. Значення показника формується на основі суми справедливої вартості довгострокових фінансових інвестицій, що збільшується або зменшується на частку інвестора в фінансових результатах підприємств або в результаті переоцінки, знецінення таких інвестицій.

Планування подальшої діяльності суб'єктів господарювання напряму залежить від прогнозної вартості довгострокових фінансових інвестицій. Математичне моделювання зміни вартості довгострокових інвестицій Групи передбачає: визначення рівняння регресії, оцінку вірогідності існування тенденції, помилки апроксимації та 
визначення прогнозного значення вартості довгострокових фінансових інвестицій Групи 3 його нижніми та верхніми межами на 5 років. Розрахунки показників моделі виконуються за допомогою прикладних інструментів Microsoft Excel.

Визначимо рівняння регресії моделі методом найменших квадратів та позначимо визначене рівняння з розрахунковим значенням коефіцієнта детермінації $\mathrm{R}^{2}$ на рисунку 1 .

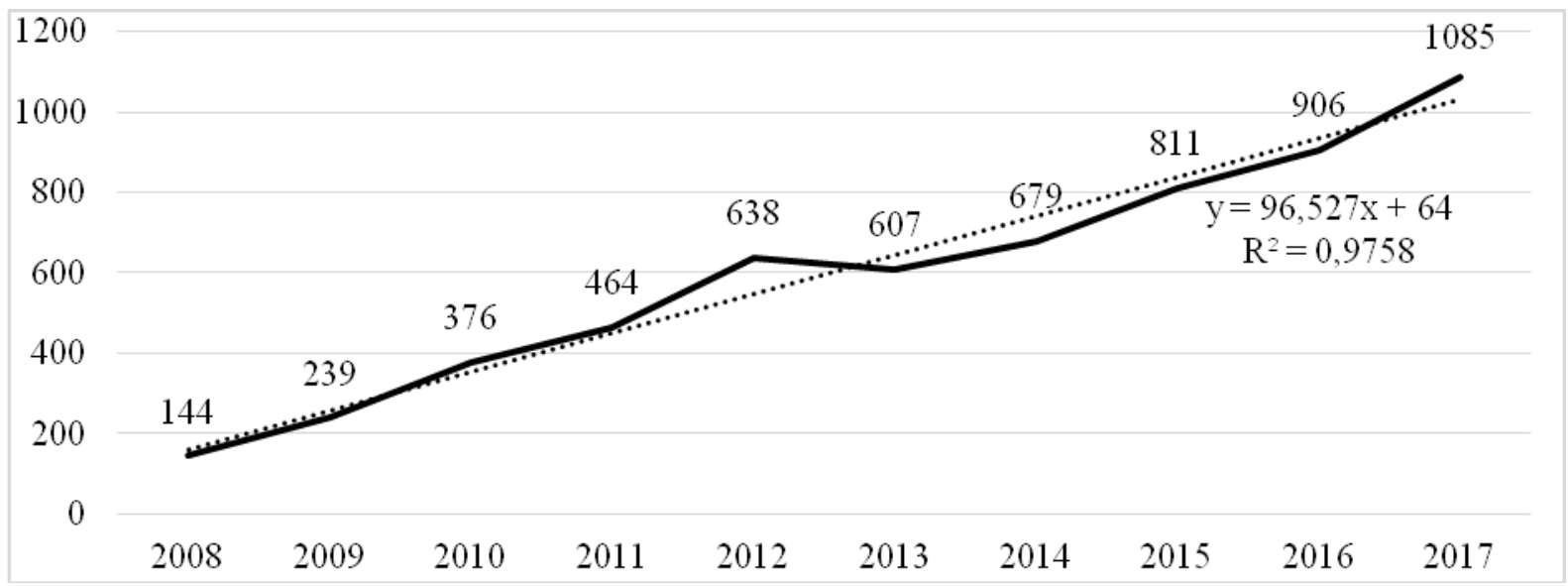

Рисунок 1 - Зміна вартості довгострокових фінансових інвестицій Групи «Метінвест» за $2008-2017$ pp.

Лінійне рівняння регресії має вигляд прямої $\mathrm{y}=\mathrm{kx}+\mathrm{b}$, тобто $\mathrm{y}=96,527 \mathrm{x}+64$. Економічна інтерпретація такого рівняння пояснює, що щорічна вартість довгострокових фінансових інвестицій Групи підвищується на 96,53 тис. дол.

Оцінка якості побудованої моделі відбувається при визначенні абсолютної помилки апроксимації, що розраховується, як середнє відхилення розрахункових значень від фактичних. За нашими підрахунками абсолютна помилка апроксимації $\varepsilon$ складає 6,84\%, допустиме значення показника повинно бути в межах 5-7\%.

Отже, у середньому розрахункові значення відрізняються від фактичних на $6,84 \%$, таке відхилення є прийнятним, наведене вище рівняння можна використовувати як рівняння регресії.

Візуалізація прогнозної вартості довгострокових фінансових інвестицій Групи «Метінвест» наведена на рисунку 2. Отже, враховуючи щорічне знецінення рівнів ряду динаміки на $20 \%(\alpha=0,2), 3$ імовірністю 0,95 можна стверджувати, що в 2018 році вартість довгострокових фінансових інвестицій може скласти 1126 млн. дол., при цьому можливий розкид розміру від 989 до 1262 млн. дол.



Рисунок 2 - Вартість довгострокових фінансових інвестицій за 2008 - 2022 рр. 
Аналогічно в 2019 р вартість довгострокових фінансових інвестицій може скласти 1222 млн. дол., при цьому можливе коливання від 1079 до 1365млн. дол; в 2020 p - 1319 млн. дол., при цьому можливе коливання вартості від 1168 до 1469 млн. дол; в 2021 - 1415 млн. дол., при цьому можливе коливання вартості від 1257 до 1574 млн. дол .; в 2021 - 1512 млн. дол., при цьому можливе коливання від 1345 до 1679 млн. дол.

Висновки. Узагальнення результатів горизонтального аналізу, аналізу фінансової стійкості та визначення типу фінансової стійкості характеризує ПрАТ «ЦГЗК», як стабільне, інвестиційно привабливе та фінансово стійке підприємство Групи. ПрАТ «ІнГЗК» має середній рівень фінансової стабільності, інвестиційної привабливості та фінансової стійкості. ПрАТ «ПівнГЗК», не дивлячись на високий рівень фінансової стабільності, за рахунок зростання залежності від позикового капіталу та скорочення прибутків, знаходиться у кризовому стані.

Для гірничо-збагачувальних комбінатів Групи існує загроза потенційної неплатоспроможності, що пояснюється низькими показниками коефіцієнтів ліквідності підприємств, також, різка зміна типів фінансової стійкості негативно впливає на рівень довіри потенційних та реальних інвесторів. Для підвищення рівня інвестиційної привабливості рекомендовано збільшення прибутковості при збільшенні позитивного чистого грошового потоку, що стане запорукою підвищення платоспроможності.

\section{Література:}

1. Державна служба статистики України. URL: http://www.ukrstat.gov.ua/ (дата звернення: 05.12.2018)

2. Бланк А. I. Управління використанням капіталу. Особливості форми фінансового інвестування капіталу. URL:http://ibrary.if.ua/book/157/10282.html (дата звернення: 25.11.2018)

3. Report on the consolidated summary financial statements Metinvest B.V.: Офіційний сайт Міжнародної вертикально інтегрованої гірничо-металургійної групи компаній «Метінвест». URL: https://www.metinvestholding.com/ua (дата звернення: 21.10.2018)

4. Савицька Г.В. Економічний аналіз діяльності підприємства: навч. посібник. Київ : Знання. 2007. 668 с.

5. Русіна Ю. О., Полозук Ю. В. Економічна сутність фінансової стійкості підприємства та фактори, що на неї впливають. International Scientific Journal, 2015. №2. C. $91-94$

6. Іонін Є.С., Овчинникова М.М. Фінансова аналітика сучасного бізнесу: монографія. Донецьк. ДонНУ. 2012. - 304 с.

7. Іонін Є.Є. Обліково-аналітичні засади стратегічного фінансового планування. Фінанси, облік, банки. Науковий журнал, № 1 (22)-2017. Вінниця-2017. C.23-33. 